\title{
Analisis Kemampuan Pemahaman Konsep Matematis Peserta Didik Pada Penerapan E-Learning Berbasis Google Classroom
}

\author{
Lestari Hernawati ${ }^{1}$, Trisna Roy Pradipta ${ }^{2}$ \\ ${ }^{1,2}$ Program Studi Pendidikan Matematika, Fakultas Ilmu Pendidikan, Universitas Muhammadiyah Prof. Dr. Hamka, \\ Jl. Tanah Merdeka No. 2, Jakarta Timur, Indonesia \\ Lestarihernawati9@gmail.com
}

\begin{abstract}
This study aims to analyze the ability of students to understand mathematical concepts in solving matrix problems in the application of e-learning based on google classroom. This research method uses a qualitative method with a descriptive approach. This study describes the ability to understand mathematical concepts that students have in the process of learning mathematics with the help of google classroom. The subjects used in this study were students of class X Accounting at SMKN 1 Tambun Utara as many as 30 students during the current covid-19 period. The data collection used is in the form of an ability test for understanding mathematical concepts and interviews. Based on the results of research showing that the ability to understand concepts of students based on Google Classroom is able to provide a better understanding of the matrix material, it is shown at a highlevel ability with a percentage of $67 \%$. ability level. However, students showed a positive response to the google classroom learning media.
\end{abstract}

Keywords: understanding mathematical concepts, Google Classroom

\begin{abstract}
Abstrak
Penelitian ini bertujuan untuk menganalisis kemampuan pemahaman konsep matematis peserta didik dalam menyelesaikan masalah matriks pada penerapan e-learning berbasis google classroom. Metode penelitian ini menggunakan metode kualitatif dengan pendekatan deskriptif. Penelitian ini mendeskriptifkan kemampuan pemahaman konsep matematis yang dimiliki peserta didik dalam proses pembelajaran matematika dengan bantuan google classroom. Subjek yang digunakan dalam penelitian ini adalah peserta didik kelas X Akuntansi di SMKN 1 Tambun Utara sebanyak 30 peserta didik pada masa covid-19 saat ini. Pengumpulan data yang digunakan berupa tes kemampuan pemahaman konsep matematika dan wawancara. Berdasarkan hasil penelitian yang menunjukkan bahwa kemampuan pemahaman konsep peserta didik berbasis google classroom mampu memberikan pemahaman yang lebih terhadap materi matriks, ditunjukkan pada kemampuan tingkat tinggi dengan hasil presentase $67 \%$, untuk lebih memperkuat hasil akan diambil sampel yaitu 6 peserta didik untuk melakukan wawancara dengan berbagai tingkat kemampuan. Namun demikian, peserta didik menunjukkan respon positif terhadap media pembelajaran google classroom.
\end{abstract}

Kata kunci: Pemahaman konsep matematik, Google Classroom

Copyright (c) 2021 Lestari Hernawati, Trisna Roy Pradipta

$\square$ Corresponding author: Lestari Hernawati

Email Address: lestarihernawati9@gmail.com (Jl. Tanah Merdeka No. 20, Jakarta Timur, Indonesia)

Received 10 Juni 2021, Accepted 16 Juni 2021, Published 17 Juni 2021

\section{PENDAHULUAN}

Adanya pandemi wabah Corono Virus Disease atau dikenal dengan Covid-19 telah menyerang seluruh penjuru dunia perlu dilakukannya jaga jarak antar sesama (Social Distance) dan tidak melakukan kontak fisik (Phyisical Distance) untuk memutus rantai penyebaran virus ini. Oleh karena itu, sejak Maret 2020 sudah terhitung 10 bulan pelaksaan belajar mengajar peserta didik dilakukan secara jarak jauh atau belajar dirumah, salah satunya proses pembelajaran pada mata pelajaran matematika. Matematika adalah salah satu mata pelajaran yang wajib dalam dunia pendidikan. Asri, Ruslan, \& Asdar (2020) mengungkapkan bahwa betapa pentingnya mempelajari matematika sejalan dengan tuntutan perkembangan zaman, selain itu matematika juga dapat digunakan untuk mengasah pola pikir seseorang agar dapat mengaplikasikan keterampilan yang dimiliki untuk menyelesaikan permasalahan dalam kehidupan sehari- 
hari, sehingga matematika sebagai salah satu mata pelajaran disekolah yang harus dipelajari oleh peserta didik dari jenjang sekolah dasar hingga perguruan tinggi. Mengingat pentingnya proses pembelajaran terutama peran pada matematika ini, dalam pembelajaran matematika sangat ditekankan mengenai pemahaman konsep matematis peserta didik. Konsep yang ada dalam matematika bersifat hierarki, yang mana dalam materi pembelajarannya saling berkaitan antara yang satu dengan yang lain (Hoiriyah, 2019).

Kemampuan pemahaman konsep matematis adalah salah satu tujuan penting dalam pembelajaran, karena dengan memahami konsep matematis peserta didik tidak hanya sekedar menghafal rumus tapi memahami konsep sebuah materi yang dipelajari dalam pembelajaran matematika (Savira \& Suharsono, 2020). Menurut Hasanah \& Istiqomah (2017) bahwa pemahaman dapat diartikan dari kata understanding dimana derajat pemahaman ditentukan oleh tingkat keterkaitan suatu gagasan, prosedur atau fakta matematika dapat dipahami secara menyeluruh jika hal-hal tersebut membentuk jaringan dengan keterkaitan yang tinggi, dan konsep artinya sebagai ide abstrak yang dapat digunakan untuk menggolongkan sekumpulan objek. Oleh karena itu, pemahaman konsep matematis termasuk kedalam tujuan utama dalam pembelajaran matematika sesuai dengan Permendiknas No.22 tahun 2006 yang menyatakan bahwa tujuan pembelajaran matematika yaitu memahami konsep matematika, menjelaskan keterkaitan antar konsep dan mengaplikasikan konsep atau algoritma secara luwes, akurat, efisien dan tepat dalam pemecahan masalah.

Pemahaman konsep merupakan dasar dari pemahaman prinsip dan teori-teori, sehingga untuk memahami prinsip dan teori terlebih dahulu siswa harus memahami konsepkonsep yang menyusun prinsip dan teori tersebut,karena itu hal yang sangat fatal apabila siswa tidak memahami konsep-konsep matematika (Diana, Marethi, \& Pamungkas, 2020).

Indikator pemahaman konsep matematis dalam penelitian ini adalah: (Pratiwi, 2016).

a) Menyatakan ulang sebuah konsep.

b) Mengklasifikasikan objek menurut tertentu sesuai dengan sifatnya.

c) Memberikan contoh dan bukan contoh dari suatu konsep.

d) Menyajikan konsep dalam berbagai bentuk representasi matematis.

e) Mengembangkan syarat perlu atau syarat cukup dari suatu konsep.

f) Menggunakan dan memanfaatkan serta memilih prosedur atau operasi tertentu.

g) Mengaplikasikan konsep atau algoritma dalam pemecahan masalah.

Dengan kondisi sekarang ini diberlakukan pelaksaan pembelajaran secara online atau daring ditingkat SD hingga perguruan tinggi sesuai anjuran pemerintah sehingga para pendidik dituntut untuk menggunakan media pembelajaran yang sesuai dengan kebutuhan materi. E-learning merupakan segala aktivitas belajar yang menggunakan bantuan teknologi elektronik. E-learning juga dapat diaplikasikan dalam pendidikan konvensional dan pendidikan jarak jauh, Web-Based Learning merupakan salah satu bentuk e-learning yang materi (content) maupun cara penyampaiannya (delivery menthode) melalui internet (web) (Derivat, 2020). E-Learning merupakan salah satu penerapan teknologi internet dalam penyampaian pembelajaran dalam jangkauan luas yang berlandaskan tiga kriteria, yaitu : E-learning merupakan jaringan dengan kemampuan memperbaharui, menyimpan, mendistribusikan dan membagi materi ajar atau informasi, Pengiriman 
sampai ke pengguna terakhir melalui komputer dengan menggunakan teknologi internet yang standar (Wardono, Waluya, Kartono, Mulyono, \& Mariani, 2018).

Menurut Suyanto (2005) ada beberapa kelebihan dan kekurangan yang dimiliki oleh e-learning dalam proses pembelajaran, yaitu :

1. Kelebihan e-learning

a. Tersedianya fasilitas e-moderating di mana pendidik dan peserta didik dapat berkomunikasi secara mudah melalui fasilitas internet secara reguler dan kapan saja kegiatan komunikasi itu dilakukan dengan tanpa dibatasi oleh jarak, tempat dan waktu.

b. Pendidik dan peserta didik dapat menggunakan bahan ajar atau petunjuk belajar yang terstruktur dan tgerjadwal melalui internet, sehingga keduanya bisa saling menilai sampai seberapa jauh bahan ajar yang dipelajar.

c. Mahasiswa dapat belajar atau me-review bahan perkuliahan setiap saat dan dimana saja kalau diperlukan mengingat bahan ajar tersimpan dalam komputer.

d. Jika peserta didik memerlukan tambahan informasi yang berkaitan dengan bahan yang dipelajarinya, ia dapat melakukan akses internet secara lebih mudah.

e. Baik pendidik maupun peserta didik dapat melakukan diskusi melalui internet yang dapat diikuti dengan jumlah peserta yang banyak, sehinga menambah ilmu pemngetahuan dan wawasan yang lebih luas.

f. Berubahnya peran peserta didik dari biasanya pasif menjadi aktif.

g. Relatif lebih efesien, misalnya bagi mereka yang tidak jauh dari pergutruan tinggi atau sekolah konvensional.

2. Kekurangan e-learning

a. Kurangnya interaksi antara pendidik dan peserta didik atau bahkan antar siswa itu sendiri. Kurangnya interaksi ini bisa memperlambat terbentuknya values dalam proses pembelajaran.

b. Kecendrungan mengabaikan aspek akademik atau aspek sosial dan sebaliknya mendorong adanya aspek bisnis/komersial.

c. Proses pembelajaran cendrung ke arah pekatihan daripada pendidikan.

d. Berubahnya peran dosen dari yang tadinya menguasai teknik konvensional, kini dituntut juga mengetahui teknik pembelajaran yang menggunakan ICT.

e. Mahasiswa yang tidak mempunyai motivasi belajar yang tinggi cendrung gagal.

f. Tidak semua tempat tersedia fasilitas internet.

g. Kurangnya porsenil dalam hal penguasaan bahasa pemrograman komputer.

Pada saat ini sudah banyak media pembelajaran e-learning yang telah dikembangkan untuk peserta didik agar menyukai pelajaran matematika mulai dari sekedar berbasis power point dikelas, menuju ke sistem LMS (Learning Management System). LMS adalah aplikasi perangkat lunak atau teknologi berbasis web yang digunakan untuk merencanakan, melaksanakan, dan menilai proses pembelajaran tertentu. Google Classroom merupakan salah satu dari beberapa Learning Management system (LMS) yang 
memberikan fasilitas kepada pendidik dan peserta didik untuk berinteraksi satu sama lain, bertukar informasi secara online (Salamah, Lindawati, Fadhli, \& Kusumanto, 2020).

Google Classroom adalah aplikasi buatan Google yang dikhususkan untuk pembelajaran online (daring) atau yang lebih dikenal dengan kelas online sehingga dapat memudahkan pendidik dan pengajar dalam melaksanakan proses pembelajaran kapan saja dan dimana saja tanpa terikat jarak dan waktu (Rangkuti, 2019). Google Classroom merupakan salah satu media pembelajaran e-learning di indonesia Google Classroom yang bersifat interaktif yang dilengkapi dengan fasilitas komunikasi antara pelajar dengan pengajar, antar sesama pelajar, dan pelajar dengan sumber belajar lain (Sudibjo, 2019). Menurut (Biantaro, 2014 dalam Wicaksono, 2020) Google Classroom merupakan alat produktivitas gratis meliputi email, dokumen dan penyimpanan. Classroom di desain untuk memudahkan guru (pengajar) dalam menghemat waktu, mengelola kelas, dan meningkatkan komunikasi dengan peserta didiknya. Dengan Google Classroom ini dapat memudahkan peserta didik dan guru untuk saling terhubung meskipun diluar kelas.

Menurut (Hikmatiar, Sulisworo, \& Wahyuni, 2020) menyatakan kelebihan dan kekurangan dari Google Classroom antara lain yaitu :

1. Kelebihan: dengan menggunakan google classroom guru dapat mengontrol bahkan lebih dari satu kelas sekaligus, lebih mudah memberikan pengumuman tentang pelajaran, memudahkan akses siswa dan guru, waktu yang dimiliki guru dan siswa dalam berkomunikasi lebih banyak, bisa mengirim tugas (file atau vidio).

2. Kekurangan: tidak mudah mengontrol siswa dalam menanggapi respon yang diberikan guru, hasil pengerjaan tugas lebih mudah di jiplak (ketidak jujuran akademis), tidak semua sekolah bisa menggunakan google classroom dikarenakan masalah jaringan, kecepatan jaringan menjadi kendala dari penggunaan google classroom, file yang sering hilang saat diunggah, tidak mudah bagi pengguna yang berasal dari pedesaan yang kurang memahami teknologi.

Berdasarkan uraian di atas, maka dapat disimpulkan bahwa pembelajaran yang dilakukan dengan menggunakan e-learning berbasis media Google Classroom dapat menumbuhkan semangat belajar peserta didik dan kemampuan peserta didik dalam memahami materi lebih mendalam yang berimplikasi terhadap meningkatnya hasil belajar. Tujuan dari penelitian ini adalah untuk mengetahui dan menganalisis kemampuan pemahaman konsep matematika peserta didik dalam menyelesaikan soal pemahaman konsep matematika materi matriks berbasis Google Classroom.

\section{METODE}

Penelitian yang dilakukan merupakan penelitian kualitatif dengan menggunakan metode deskriptif untuk menganalisis kemampuan pemahaman konsep matematis peserta didik dalam menyelesaikan soal matriks. Subjek penelitian ini yaitu peserta didik kelas X Akuntansi, yang dilakukan di SMKN 1 Tambun Utara tahun ajaran 2020/2021. Teknik pengambilan sampel yang dilakukan yaitu dengan menggunakan teknik bertujuan atau purposive sampling yang merupakan salah satu jenis Nonprobability sampling. 
Menurut Fitri \& N Haryanti (2020) Nonprobability sampling adalah teknik pengambilan sampel yang tidak memberi peluang/kesempatan sama bagi setiap unsur atau anggota populasi untuk dipilih menjadi sampel. Purposive sampling merupakan teknik penentuan sampel dengan pertimbangan tertentu (Derivat, 2020). Pengumpulan data dalam penelitian ini yaitu menggunakan instrument tes dan wawancara. Pada penelitian ini data yang digunakan merupakan instrument tes kemampuan pemahaman konsep yang sudah di validasi oleh dosen. Tes yang akan diberikan kepada peserta didik sejumlah 7 soal essay, dan melakukan wawancara mengambil 6 sampel yaitu 6 peserta didik dalam berbagai tingkat kemampuan. Dengan demikian, instrument tes yang digunakan dapat mendeskripsikan kemampuan pemahaman konsep matematika yang dimiliki peserta didik terhadap materi matriks. Dibawah ini bagan roadmap penelitian pada gambar berikut:

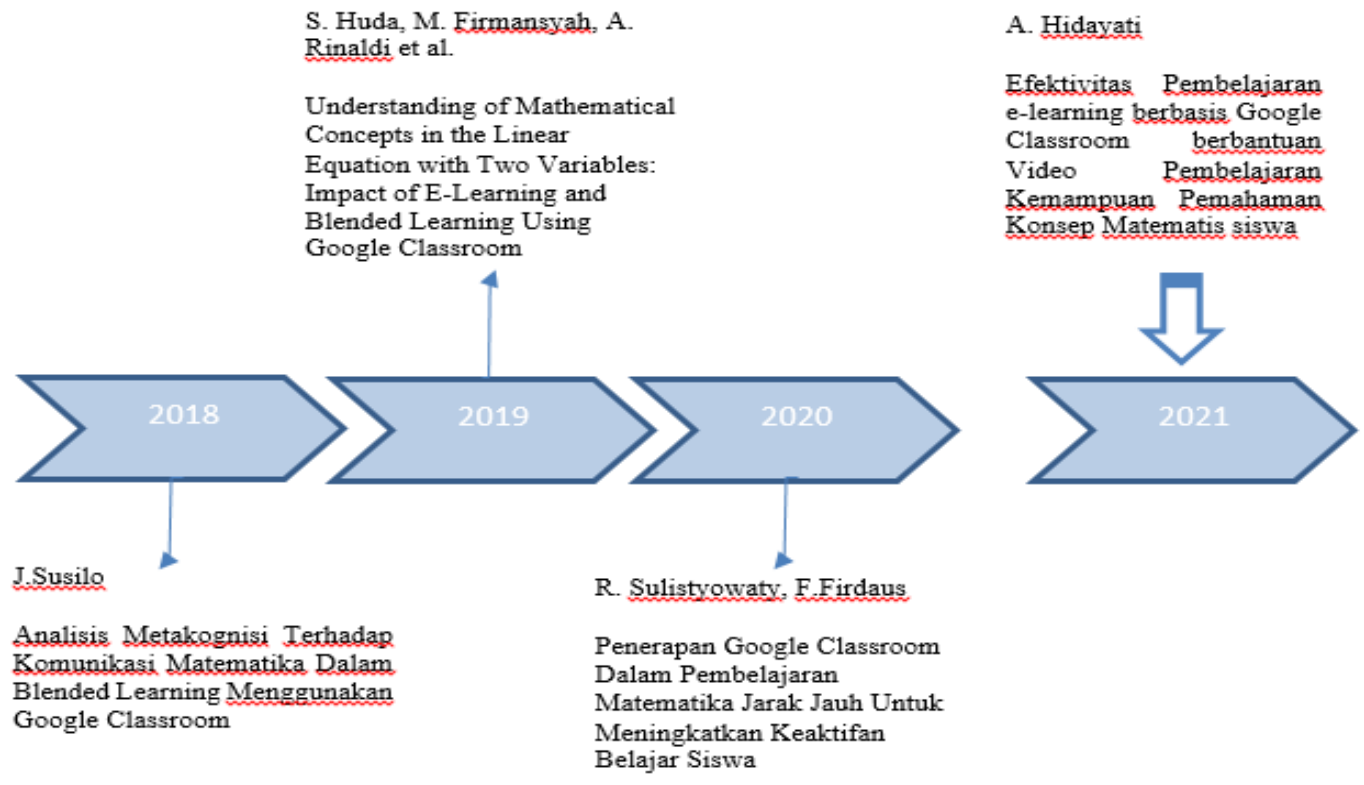

Gambar 1. Bagan Roadmap Penelitian

\section{HASIL DAN DISKUSI}

Dalam penelitian ini, peserta didik menggunakan google classroom pada proses pembelajaran matematika. Penerapan e-learning berbasis google classroom ini untuk mengetahui kemampuan pemahaman konsep siswa kelas X di SMKN 1 Tambun Utara dengan menggunakan insturumen tes dan wawancara. Tes kemampuan pemahaman konsep matematika diberikan untuk mengukur sejauh mana pemahaman peserta didik terhadap materi matriks yang diberikan melalui bantuan media pembelajaran Google Classroom. Tes tersebut terdapat 7 soal essay yang diujikan setelah peserta didik mendapatkan penjelasan materi matriks dikelas X. Masing-masing soal tersebut diberi skor maskimal 4.

Melalui penggunaan media pembelajaran google classroom dalam pengerjaan soal, terdapat peserta didik yang mengalami keterlambatan pada saat mengumpulkan soal, tetapi hal tersebut dapat diatasi karena meskipun ada pembatasan waktu yang diberikan dalam menyelesaikan soal tetap dapat mensubmit hasil pengerjaan setiap peserta didik; 


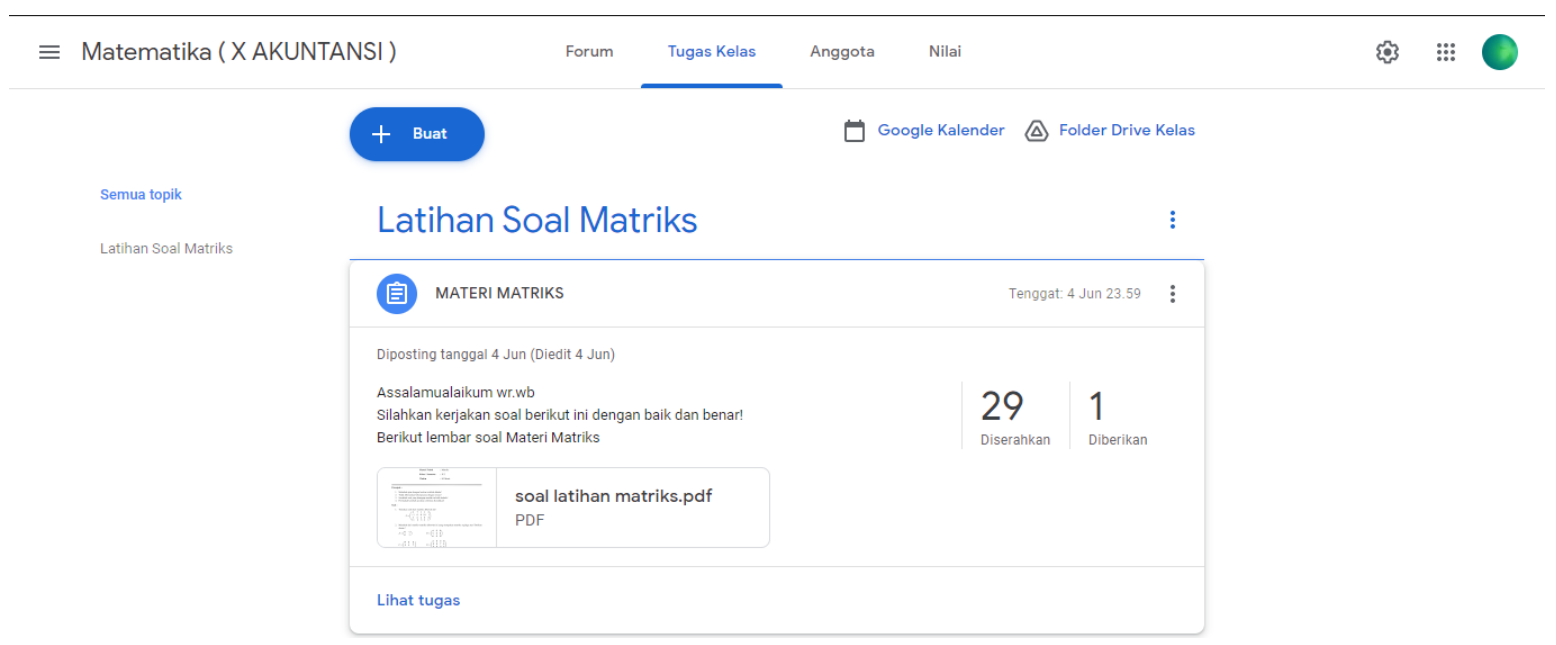

Gambar 2. Soal Materi Matriks

Adapun hasil dan skor dari pengerjaan yang dilakukaan oleh peserta didik dalam gambar berikut:

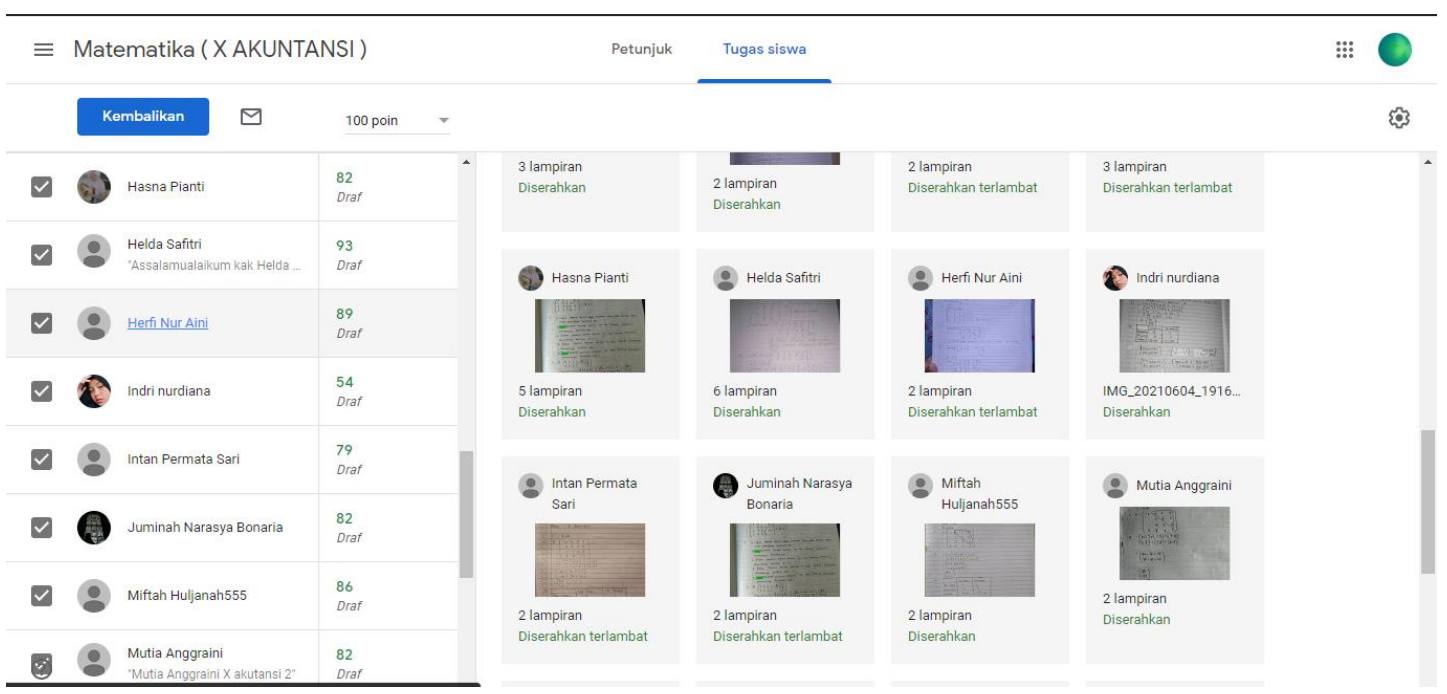

Gambar 3. Skor dan hasil dari Pengerjaan Peserta Didik

Penelitian ini terdapat 30 peserta didik yang mengerjakan soal materi matriks melalui google classroom berisikan 7 soal essay. Berikut hasil menunjukkan bahwa tingkat kemampuan pemahaman konsep matematis peserta didik di kelas X Akuntansi SMKN 1 Tambun Utara dominan tinggi. Berikut ini disajikan hasil presentase kemampuan pemahaman konsep peserta didik.

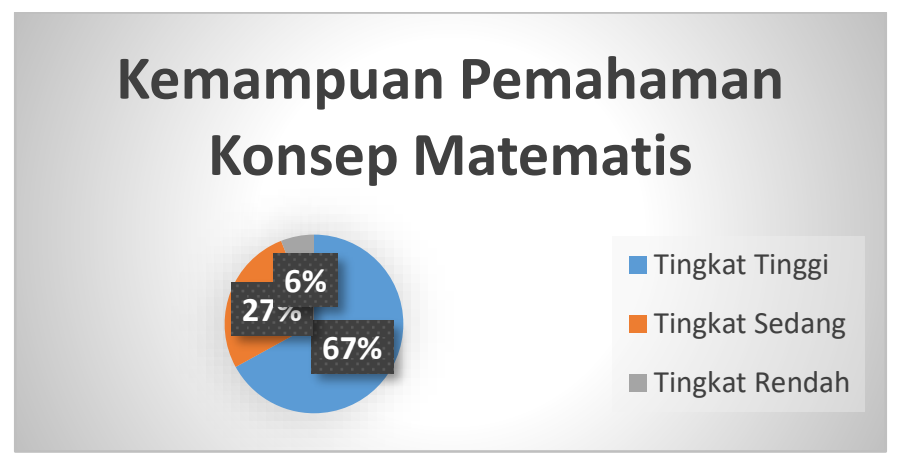

Gambar 4. Hasil presentase kemampuan pemahaman konsep peserta didik 
Diagram di atas memperlihatkan kemampuan pemahaman konsep peserta didik lebih banyak berada di tingkat tinggi. Hasil dari tes kemampuan pemahaman konsep peserta didik tersebut yang tergolong dalam tingkat rendah berjumlah $6 \%$ di tingkat sedang $27 \%$ dan di tingkat tinggi $67 \%$.

Table berikut adalah sampel dari jumlah peserta didik yang memuat dalam kemampuan tingkat rendah, sedang, dan tinggi.

Table 1. Hasil dari Intrumen Tes Kemampuan Pemahaman Konsep Matematis

\begin{tabular}{|c|l|c|c|c|c|c|c|c|c|c|}
\hline \multirow{2}{*}{ No } & \multicolumn{1}{|c|}{ Nama } & \multicolumn{7}{|c|}{ Soal Matriks } & \multirow{2}{*}{ Nilai } & \multirow{2}{*}{ Tingkat Kemampuan } \\
\cline { 3 - 10 } & & $\mathbf{1}$ & $\mathbf{2}$ & $\mathbf{3}$ & $\mathbf{4}$ & $\mathbf{5}$ & $\mathbf{6}$ & $\mathbf{7}$ & & \multirow{2}{*}{ Kemampuan Rendah } \\
\hline 1 & Indri Nurdiana & 4 & 1 & 3 & 4 & 3 & 0 & 0 & 54 \\
\hline 2 & Aron Kukuh Prabowo & 4 & 2 & 4 & 4 & 3 & 3 & 0 & 71 \\
\hline 3 & Juminah Narasya Bonaria & 4 & 2 & 4 & 4 & 4 & 3 & 2 & 82 & \multirow{2}{*}{ Kemampuan Sedang } \\
\hline 4 & Hasna Pianti & 4 & 2 & 4 & 4 & 4 & 3 & 2 & 82 & \multirow{2}{*}{ Kemampuan Tinggi } \\
\hline 5 & Aldilah Arisyasya & 4 & 2 & 4 & 4 & 4 & 4 & 4 & 93 \\
\hline 6 & Farah Salsabila & 4 & 2 & 4 & 4 & 4 & 4 & 4 & 93 & \\
\hline
\end{tabular}

Dari hasil tes yang sudah di dapatkan, peneliti akan mengambil sampel untuk memperkuat hasil dari tes kemampuan pemahaman konsep matematis yang telah dikerjakan oleh peserta didik dengan melalakukan wawancara kepada peserta didik dan guru. Sampel yang akan diambil oleh peneliti yaitu 2 peserta didik dari kemampuan pemahaman konsep matematis tingkat rendah, 2 peserta didik dari kemampuan pemahaman konsep matematis tingkat sedang, dan 2 peserta didik dari kemampuan pemahaman konsep matematis tingkat tinggi. Berikut hasil dari wawancara yang telah peneliti lakukan dengan responden.

\section{Hasil Analisis Kemampuan Pemahaman Konsep Peserta Didik Pada Kategori Tingkat Tinggi}

Dalam menganalisis kemampuan pemahaman konsep matematis peserta didik pada penerapan $e$ learning berbasis google classroom dilakukan wawancara melalui secara daring video call whatsapp. Berdasarkan hasil tes kemampuan pemahaman konsep peserta didik yang mendapatkan hasil skor 93 dari 100 mengatakan bahwa dapat memahami konsep matematis pada materi matriks karena peserta didik tersebut sudah mengerti apa yang telah dijelaskan sebelumnya, karena peserta didik merasa bahwa butuh penjelasan terlebih dahulu, sebelum mengerjakan soal meskipun terdapat satu jawaban yang peserta didik merasa keliru dalam menyelesaikan soal. Dari hasil tersebut peneliti bisa menyimpulkan bahwa peserta didik dikategorikan dalam kemampuan tingkat tinggi karena kemampuan yang dimiliki peserta didik sangat memuaskan, seperti saat mengerjakan tes peserta didik mampu menjawab semua hanya satu soal yg membuat dia agak sedikit kesulitan. Untuk meningkatkan kemampuan pemahaman konsep matematis, peserta didik membutuhkan ketelitian dan fokus dalam menyelesaikan soal tersebut dengan benar dan tepat sehingga peserta didik dapat memiliki kemampuan pemahaman konsep peserta didik yang lebih tinggi.

Peserta didik kedua yang diwawancarai melalui video call whatsapp memperoleh skor tes 93 dari 100. Dari hasil wawancara mengenai kemampuan pemahaman konsep pada materi matriks, peserta didik tersebut mengungkapkan bahwa sudah memahami penjelasan yang telah diberikan mengenai penyelesaian soal pada materi tersebut. Namun, terdapat kesalahan yang sama dengan peserta didik yang diwawancarai pertama, dimana perserta didik tersebut merasa sedikit kebingungan dan keliru serta kurangnya ketelitian 
dalam perhitungan pada proses pengerjaan soal. Meskipun demikian peserta didik ini mengatasi hal tersebut dengan memahami kembali konsep-konsep yang masih sulit dipahami dari jawaban yang kurang tepat. Oleh karena itu, dapat disimpulkan bahwa peserta didik tersebut memiliki kemampuan pemahaman konsep matematis dengan kategori tingkat tinggi.

\section{Hasil Analisis Kemampuan Pemahaman Konsep Matematis Peserta Didik Pada Kategori Tingkat Sedang}

Pada pemahaman konsep matematis dengan kategori tingkat sedang, peserta didik pertama memperoleh skor 82 dari 100. Ketika melakukan wawancara melalui video call Whatsapp, peserta didik tersebut dapat dikatakan cukup memahami pemahaman konsep matematis pada materi yang telah dijelaskan dan mampu menyelesaikan soal. Namun peserta didik sedikit mengalami kesulitan akan proses mengerjakan soal yang telah diberikan dan peserta didik tersebut merasa sedikit ragu mengenai jawaban yang telah dikerjakannya. Oleh karena itu, peserta didik tersebut memeriksa kembali jawaban yang telah dikerjakan. Sehingga untuk mendapatkan solusi dalam menyelesaikan latihan soal, peserta didik perlu mengembangkan pemahaman konsep matematis. Dari hasil wawancara yang telah dilaksanakan peneliti dapat disimpulkan, peserta didik tersebut termasuk dalam kategori kemampuan pemahaman konsep tingkat sedang.

Peserta didik kedua yang mendapatkan skor 82 dari 100 melalukan wawancara secara daring melalui video call Whatsapp, peserta didik ini tergolong dalam kemampuan pemahaman konsep matematis tingkat sedang. Pada saat diwawancarai, peserta didik tersebut mengatakan bahwa ia mampu memahami konsep matemastis dalam menyelesaikan soal yang ada pada instrument tes yang telah diberikan. Namun, ketika terdapat soal-soal yang dianggap sulit, peserta didik memberikan alasan bahwa dengan cara mempelajari kembali materi yang sudah disampaikan dan menjawab soal hingga mendapatkan jawaban yang benar dan tepat untuk meningkatkan pemahaman konsep matematis peserta didik tersebut. Berdasarkan hasil wawancara dari kedua peserta didik, menunjukan bahwa dapat memahami konsep matemastis pada materi matriks dengan cukup baik

\section{Hasil Analisis Kemampuan Pemahaman Konsep Matematis Peserta Didik Pada Kategori Tingkat Rendah}

Berdasarkan hasil wawancara secara daring melalui video call whatsapp. terdapat peserta didik kedua dengan kemampuan pemahaman konsep matematis tingkat rendah, untuk peserta didik pertama ini memperoleh skor 54 dari 100, ia mengatakan sedikit mampu memahami konsep dalam meneyelesaikan soal namun ketika mengerjakan latihan-latihan soal yang berbeda dari contoh pembahasan yang telah dijelaskan, perserta didik tersebut tidak mampu menyelesaikannya karena kurang menguasai materi tersebut dan hanya terpaku pada contoh soal yang telah diberikan. Sehingga peserta didik tidak mampu menjawab beberapa soal dengan mengkosongkan jawaban serta mendapatkan nilai yang cukup rendah. Maka dari itu, dari hasil wawancara yang peniliti telah laksanakan, peserta didik perlu lebih banyak mempelajari soal-soal agar peserta didik tersebut mempunyai pemahaman konsep matematis.

Peserta didik kedua memperoleh skor tes yaitu 71 dari 100 dan termasuk dalam kategori kemampuan pemahaman konsep tingkat rendah. Berdasarkan hasil wawancara secara daring melalui video 
call whatsapp, peserta didik tersebut mengatakan bahwa mengalami kesulitan dalam memahami dan menyelesaikan beberapa soal yang telah diberikan. Peserta didik tersebut merasa sudah mencoba untuk menyelesaikannya namun tidak mendapatkan jawaban yang sesuai sebab peserta didik tersebut merasa kesulitan dan kurang teliti pada saat perhitungan. Sehingga peserta didik tersebut hanya dapat menjawab beberapa soal sesuai dengan kemampuan pemahaman konsep yang dimilikinya. Dengan demikian, kemampuan pemahaman konsep matematis tingkat rendah yang dimiliki oleh peserta didik pertama ditinjau dari hasil tes dan wawancara, maka peserta didik tersebut perlu memahami konsep-konsep dalam menyelesaikan soal tersebut.

\section{KESIMPULAN}

Berdasarkan hasil pembahasan yang telah dijelaskan, peneliti dapat menyimpulkan bahwa peseerta didik sudah dapat mehamai konsep pembelajaran matematika dalam menyelesaikan soal pada materi matriks berbasis Google Classroom. Penelitian yang dilakukan di SMKN 1 Tambun Utara tahun ajaran 2020/2021. Dapat disimpulkan hasil tes kemampuan pemahaman konsep matematis peserta didik menunjukkan bahwa dua orang peserta didik dengan kategori tingkat rendah, delapan orang peserta didik dengan kategori tingkat sedang, dan dua puluh orang peserta didik dengan kategori tingkat tinggi. Hal tersebut membuktikan bahwa kemampuan pemahaman konsep matematis peserta didik kelas X di SMKN 1 Tambun Utara dikategorikan termasuk dalam tingkat tinggi.

Penelitian lebih lanjut masih sangat diperlukan, dikarenakan peserta didik perlu membutuhkan penjelasan materi secara langsung untuk memahami bagaimana cara penyelesaian soal dilihat dari keluhan peserta didik, ada yang merasa bahwa guru hanya memberikan soal tetapi tidak menjelaskannya terlabih dahulu, hal tersebut peneliti selanjutnya perlu untuk mengetahui kemampuan pemahaman konsep peserta didik lain yang masih melakukan pembelajaran secara online akibat pandemic Covid-19.

\section{UCAPAN TERIMA KASIH}

Peneliti mengucapkan banyak terima kasih kepada kedua orang tua, guru-guru SMKN 1 Tambun Utara, sahabat, dan seluruh dosen Program Studi Matematika Universitas Muhammadiyah Prof.Dr.HAMKA, serta kepada seluruh pihak yang telah membantu dalam proses penelitian ini.

\section{REFERENSI}

Asri, F. M., Ruslan, R., \& Asdar, A. (2020). Deskripsi Pemahaman Konsep Matematika Siswa Ditinjau dari Intensitas Penggunaan E-Learning Quipper Video. Issues in Mathematics Education (IMED), 3(2), $148-161$.

Derivat, J. (2020). Matematika Siswa Berbantuan Media. 7(1), 39-45.

Diana, P., Marethi, I., \& Pamungkas, A. S. (2020). Kemampuan Pemahaman Konsep Matematis Siswa: Ditinjau dari Kategori Kecemasan Matematik. SJME (Supremum Journal of Mathematics Education), 4(1), 24. https://doi.org/10.35706/sjme.v4i1.2033

Fitri, A. Z., \& N Haryanti. (2020). Metodologi Penelitian Pendidikan. Madani Media. 
Hasanah, A., \& Istiqomah. (2017). Penerapan Ajaran Tamansiswa Dalam Pembelajaran Matematika Untuk Membangun Pemahaman Konsep Siswa. Prosiding Seminar Nasional Etnomatnesia, 499-504.

Hikmatiar, H., Sulisworo, D., \& Wahyuni, M. E. (2020). Pemanfaatan Learning Manegement System Berbasis Google Classroom Dalam Pembelajaran. Jurnal Pendidikan Fisika, 8(1), 78-86. https://doi.org/10.26618/jpf.v8i1.3019

Hoiriyah, D. (2019). Analisis Kemampuan Pemahaman Konsep Matematis Mahasiswa. Logaritma: Jurnal Ilmu-Ilmu Pendidikan Dan Sains, 7(01), 123. https://doi.org/10.24952/logaritma.v7i01.1669

Pratiwi, D. D. (2016). Pembelajaran Learning Cycle 5e berbantuan GeoGebra terhadap Kemampuan Pemahaman Konsep Matematis. Al-Jabar: Jurnal Pendidikan Matematika, 7(9), 191-202.

Rangkuti, R. U. (2019). Penggunaan Aplikasi Google Classroom Sebagai Media Pembelajaran Berbasis Blended Learning Pada Mahasiswa Teknologi ... 3(1996), 888-893. Retrieved from http://digilib.unimed.ac.id/id/eprint/37336

Salamah, I., Lindawati, L., Fadhli, M., \& Kusumanto, R. (2020). Evaluasi Pengukuran Website Learning Management System Polsri Dengan Metode Webqual 4.0. Jurnal Digit, 10(1), 1. https://doi.org/10.51920/jd.v10i1.151

Savira, F., \& Suharsono, Y. (2020). PENERAPAN PEMBELAJARAN JARAK JAUH UNTUK MENINGKATKAN PEMAHAMAN KONSEP MATEMATIS SISWA SMP-IT ALAMY SUBANG. $\backslash, 01(01), 1689-1699$.

Sudibjo, A. (2019). Penggunaan Media Pembelajaran Ipa Berbasis Google Classroom Pada Materi Alat Optik Untuk Meningkatkan Respons Motivasi Dan Hasil Belajar Siswa Di Smp Negeri 4 Surabaya. Jurnal Education and Development, 7(3), 278-284.

Suyanto, A. H. (2005). MENGENAL E-LEARNING.

Wardono, Waluya, S. B., Kartono, Mulyono, \& Mariani, S. (2018). "Literasi Matematika Siswa SMP pada Pembelajaran Problem Based Learning Realistik Edmodo.” Prisma, 1, 477-497. Retrieved from https://journal.unnes.ac.id/sju/index.php/prisma/article/view/20138

Wicaksono, M. D. (2020). PEMANFAATAN GOOGLE CLASSROOM DALAM STRATEGI PEMBELAJARAN KOOPERATIF PADA MATA PELAJARAN IPS KELAS VIII Muhammad Denny Wicaksono. Jurnal Ilmu Ilmu Sosial, 17(1), 234-242. 